\title{
Preliminary Hazard Analysis for the Remote- Handled Low-Level Waste Disposal Project
}

May 2010

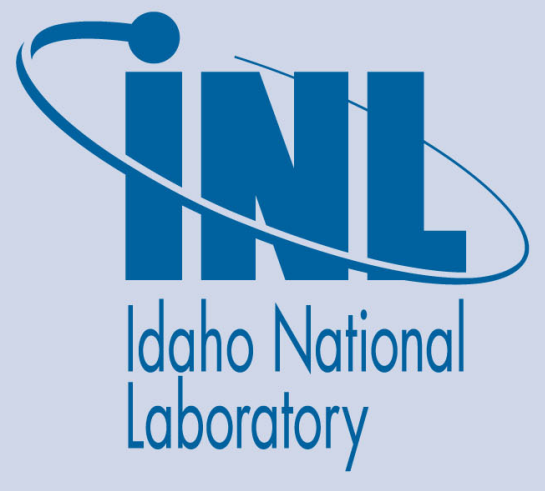

The INL is a U.S. Department of Energy National Laboratory operated by Battelle Energy Alliance 
INL/EXT-07-12903

Rev. 3

\title{
Preliminary Hazard Analysis for the Remote-Handled Low-Level Waste Disposal Project
}

May 2010

\author{
Idaho National Laboratory \\ Idaho Falls, Idaho 83415
}

http://www.inl.gov

Prepared for the U.S. Department of Energy Office of Nuclear Energy Under DOE Idaho Operations Office

Contract DE-AC07-05ID14517 


\section{DISCLAIMER}

This information was prepared as an account of work sponsored by an agency of the U.S. Government. Neither the U.S. Government nor any agency thereof, nor any of their employees, makes any warranty, expressed or implied, or assumes any legal liability or responsibility for the accuracy, completeness, or usefulness, of any information, apparatus, product, or process disclosed, or represents that its use would not infringe privately owned rights. References herein to any specific commercial product, process, or service by trade name, trade mark, manufacturer, or otherwise, does not necessarily constitute or imply its endorsement, recommendation, or favoring by the U.S. Government or any agency thereof. The views and opinions of authors expressed herein do not necessarily state or reflect those of the U.S. Government or any agency thereof. 



\begin{abstract}
The need for remote-handled low-level waste (LLW) disposal capability has been identified. A new onsite, remote-handled LLW disposal facility has been identified as the highest ranked alternative for providing continued, uninterrupted, remote-handled LLW disposal capability for remote-handled LLW that is generated as part of the nuclear mission of the Idaho National Laboratory and from spent nuclear fuel processing activities at the Naval Reactors Facility. Historically, this type of waste has been disposed of at the Radioactive Waste Management Complex. Disposal of remote-handled LLW in concrete disposal vaults at the Radioactive Waste Management Complex will continue until the facility is full or until it must be closed in preparation for final remediation of the Subsurface Disposal Area (approximately at the end of Fiscal Year 2017).

This document supports conceptual design for the proposed remote-handled LLW disposal facility by providing an initial nuclear facility hazard categorization and by identifying potential hazards for processes associated with onsite handling and disposal of remote-handled LLW.
\end{abstract}

\title{
NOTE:
}

This document analyzes the hazards for processes associated with onsite handling and disposal of remote-handled low-level waste. A new onsite facility has been identified as an alternative for providing continued remote-handled low-level waste disposal capability in support of ongoing Department of Energy missions at the Idaho site. However, a decision has not been made by the Department of Energy to develop a new onsite disposal facility. The decision, following all required analyses and evaluation of the impacts of all viable alternatives, will be made in accordance with the National Environmental Policy Act of 1969. Use of words indicating requirements or specifying intention, such as "shall" or "will," are used for the convenience of discussion or to indicate requirements or activities that are conditioned on a decision to develop a new onsite disposal facility. Such usage should not be construed to mean that a final selection of an alternative has been made. 


\section{CONTENTS}

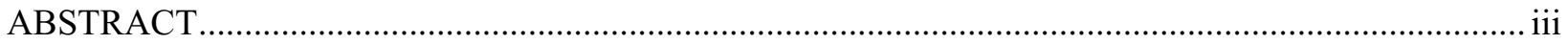

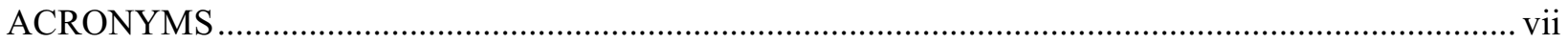

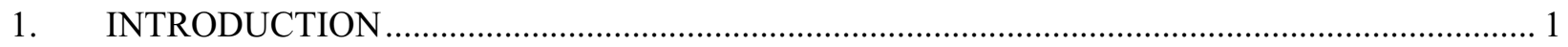

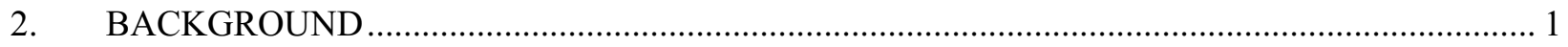

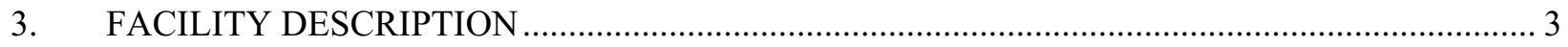

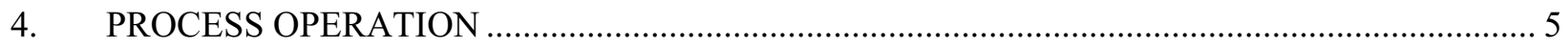

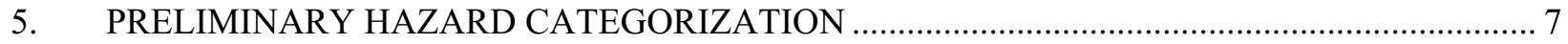

6. IDENTIFICATION OF PRIMARY FACILITY HAZARDS …........................................... 9

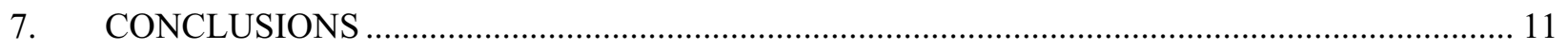

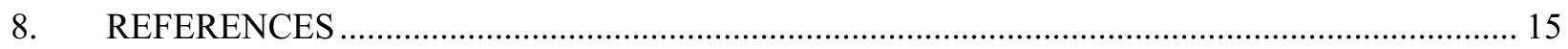

FIGURES

1. Conceptual layout of proposed concrete vault system ….......................................................... 3

2. Remote-Handled Low-Level Waste Disposal Project operational configuration ............................. 4

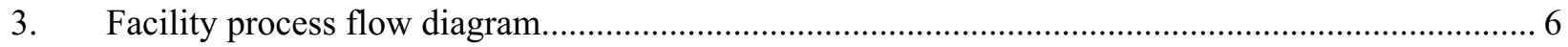

4. Cask liner placement method at the Radioactive Waste Management Complex ............................ 6

\section{TABLES}

1. Waste streams proposed for the Remote-Handled Low-Level Waste Disposal Project..................... 2

2. Preliminary hazards identified for the Remote-Handled Low-Level Waste Disposal Project......... 12 


\section{ACRONYMS}

ATR Advanced Test Reactor

CVAS cask-to-vault adapting structure

DOE Department of Energy

HC hazard category

INL Idaho National Laboratory

LLW low-level waste

NRF Naval Reactors Facility

PHA preliminary hazards analysis

RWMC Radioactive Waste Management Complex

SSC structure, system, and component 


\section{Preliminary Hazard Analysis for the Remote-Handled Low-Level Waste Disposal Project}

\section{INTRODUCTION}

This preliminary hazards analysis (PHA) for the Remote-Handled Low-Level Waste (LLW) Disposal Project is based on TFR-483, "Technical and Functional Requirements for the Remote-Handled Low-Level Waste Disposal Project," Conceptual Design Report for the Remote-Handled Low-Level Waste Facility (INL 2010a), and other associated documents. The purpose of this PHA is to perform a preliminary identification of the required safety functions and to identify a preliminary set of safety systems, structures, and components (SSCs). The hazards analyses performed in this PHA include identification of events warranting preliminary designation as design-basis accidents, hazard evaluation, and preliminary identification of major safety functions necessary to provide adequate protection, primarily for accident conditions. The hazards vary from standard industrial hazards to handling and storage of highly radioactive materials. The SSCs are identified by determination of unmitigated hazard likelihoods and consequences.

\section{BACKGROUND}

The Idaho National Laboratory (INL) routinely generates contact-handled (less than $200 \mathrm{mrem} /$ hour on contact) and remote-handled (greater than $200 \mathrm{mrem} /$ hour on contact) LLW from facility operations. Historically, INL has disposed of its LLW in a disposal facility located at the Radioactive Waste Management Complex (RWMC). This facility includes disposal pits and concrete vaults. As part of ongoing cleanup activities at INL, closure of RWMC is proceeding under the Comprehensive Environmental Response, Compensation, and Liability Act (42 USC 9601 et seq. 2006). Disposal of remote-handled LLW in concrete disposal vaults at RWMC will continue until the facility is full or until it is closed in preparation for final remediation of the Subsurface Disposal Area (approximately at the end of Fiscal Year 2017).

On July 1, 2009, the Department of Energy (DOE) approved a mission need statement for the INL Remote-Handled LLW Disposal Project to develop replacement remote-handled LLW disposal capability in support of INL's nuclear energy mission and the Naval Nuclear Propulsion Program (DOE-ID 2009). The continuing nuclear mission of INL, associated ongoing and planned operations, and Naval spent nuclear fuel activities at the Naval Reactors Facility (NRF) require continued capability to appropriately dispose of remote-handled LLW. Development of a new onsite disposal facility has been identified as the highest ranked alternative for providing continued, uninterrupted remote-handled LLW disposal capability as documented in the Remote-Handled Low-Level Waste Disposal Project Alternatives Analysis (INL 2010b).

This PHA lists and analyzes safety requirements that should be considered in implementation of the design for the Remote-Handled LLW Disposal Project, as required by DOE Order 413.3A, "Program and Project Management for the Acquisition of Capital Assets." This PHA is intended to be a living document with ongoing revisions as the design for the facility matures and the design process continues. This will ensure that Integrated Safety Management System requirements are incorporated into facility design and carried through into disposal operations in accordance with DOE Order 413.3A. In addition, all safety analysis documentation will meet the requirements of 10 CFR 830, "Nuclear Safety Management," Subpart B, "Safety Basis Requirements." 
The proposed Remote-Handled LLW Disposal Project will be designed and constructed to support disposal of remote-handled LLW waste streams generated at the Idaho site. A summary of these waste streams is provided in Table 1.

Table 1. Waste streams proposed for the Remote-Handled Low-Level Waste Disposal Project.

\begin{tabular}{|c|c|c|}
\hline $\begin{array}{l}\text { Waste } \\
\text { Stream }\end{array}$ & Generator & Description \\
\hline \multirow{2}{*}{ Resins } & $\begin{array}{l}\text { INL Advanced Test } \\
\text { Reactor (ATR) } \\
\text { Complex }\end{array}$ & $\begin{array}{l}\text { ATR produces ion-exchange resins from pool and reactor } \\
\text { operations. }\end{array}$ \\
\hline & NRF & $\begin{array}{l}\text { NRF produces ion-exchange resins from pool operations. } \\
\text { Currently, waste is disposed of in the RWMC vaults in liners that } \\
\text { are transported using a 55-ton cask. }\end{array}$ \\
\hline \multirow{3}{*}{$\begin{array}{l}\text { Activated } \\
\text { Metals }\end{array}$} & $\begin{array}{c}\text { INL } \\
\text { ATR Complex }\end{array}$ & $\begin{array}{l}\text { ATR produces activated metals during reactor core internal } \\
\text { changeout operations approximately every } 8 \text { years. These } \\
\text { components require an approximate } 8 \text {-year decay time and are in } \\
\text { storage at the ATR Complex. Previous disposal has been at } \\
\text { RWMC. }\end{array}$ \\
\hline & NRF & $\begin{array}{l}\text { NRF produces activated metals during routine operations. } \\
\text { Currently, waste is disposed of in the RWMC vaults in } 55 \text {-ton } \\
\text { scrap cask liners. }\end{array}$ \\
\hline & $\begin{array}{l}\text { INL Materials and } \\
\text { Fuels Complex }\end{array}$ & $\begin{array}{l}\text { The Materials and Fuels Complex will generate activated metals } \\
\text { during waste segregation operations for waste removed from } \\
\text { storage at the Radioactive Scrap and Waste Facility. }\end{array}$ \\
\hline Various & INL & $\begin{array}{l}\text { ATR and the Materials and Fuels Complex may produce a } \\
\text { variety of remote-handled LLW streams from new INL programs } \\
\text { and waste segregation operations at the Radioactive Scrap and } \\
\text { Waste Facility. }\end{array}$ \\
\hline
\end{tabular}

Ion-exchange resins from pool and reactor operations are generated at the ATR Complex and from pool operations at NRF. ATR ion-exchange resin is generated approximately four to six times annually from reactor loop and reactor ion-exchange systems. The generation rate depends on reactor operations and varies during the years when core internal changeouts are performed. The ion-exchange resin waste stream has typical contact exposure rates up to $15 \mathrm{R} /$ hour, although individual waste containers may have higher contact exposure rates.

ATR also produces activated metals during reactor core internal changeout operations, approximately once every 8 years. These components require decay time before they can be handled for disposal and are currently in temporary storage at the ATR Complex. NRF produces activated metals from examination of test components and during routine operations of removing irradiated non-fuel components from spent nuclear fuel modules. The activated metals waste streams have typical contact exposure rates up to $30,000 \mathrm{R} /$ hour, although individual waste containers may have higher contact exposure rates.

In addition, activated metals and other remote-handled LLW streams are expected from new INL programs and from processing of remote-handled waste stored at the Radioactive Scrap and Waste 
Facility. These materials can contain a variety of radionuclides and can have contact exposure rates up to $30,000 \mathrm{R} /$ hour, although individual waste containers may have higher contact exposure rates.

\section{FACILITY DESCRIPTION}

The proposed Remote-Handled LLW Disposal Project will be designed and constructed similar to the remote-handled LLW concrete disposal vaults currently in use in the RWMC Subsurface Disposal Area. This will accommodate, to the maximum extent possible, uninterrupted operations at the generating facilities and will capitalize on operations experience and cost efficiencies of current remote-handled LLW disposal practices. The vaults will be constructed of precast concrete cylinders (i.e., pipe sections) stacked on end and placed in a honeycomb-type array (see Figure 1). A removable concrete plug will be set on top of the stacked precast concrete cylinders to serve as a radiation shield and water barrier.

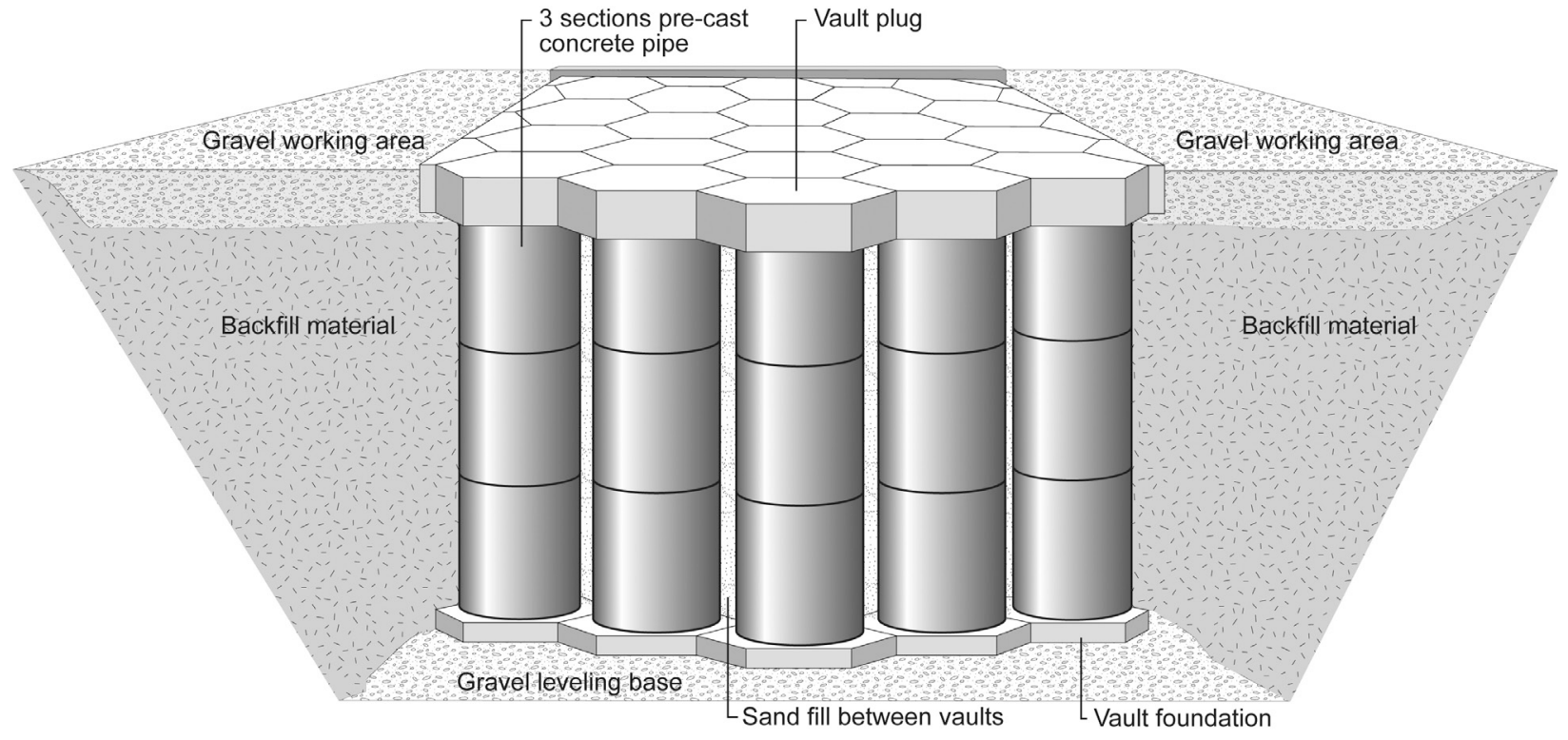

Figure 1. Conceptual layout of proposed concrete vault system.

The proposed facility layout is based on the assumption that the facility would be a stand-alone facility and would provide its own administration buildings and infrastructure to support disposal operations. If a site is selected that is located in the vicinity of an existing facility, then new construction of some of the infrastructure components may not be needed (i.e., the administration building).

The facility would be laid out in a manner to allow trucks entering the disposal facility to have straight access to the unloading area next to the disposal vaults. The crane and other miscellaneous equipment required for completion of the transportation package-to-vault transfer operation will be staged before arrival of the waste containers. Figure 2 illustrates the facility configuration and includes a photo that shows the equipment currently staged for operation at RWMC. The new facility will use these same methods and will set up the necessary equipment in a similar configuration.

The total number of vaults that will be constructed will depend on the depth of surficial sediment at the specific site that is selected for the facility. The general layout in the conceptual design report (INL 2010a) shows the areal extent of the vaults, as determined using a vault depth that can accommodate disposal of two waste containers per vault. In this configuration, a minimum of 160 vaults will be needed for NRF waste, 60 vaults for ATR resins, and 23 vaults for activated metals from ATR processing of 
co-mingled, remote-handled LLW currently stored in the Radioactive Scrap and Waste Facility and new INL programs. If the selected site has sufficient surficial sediment to accommodate three waste containers per vault, the total number of required vaults would be reduced by one-third.

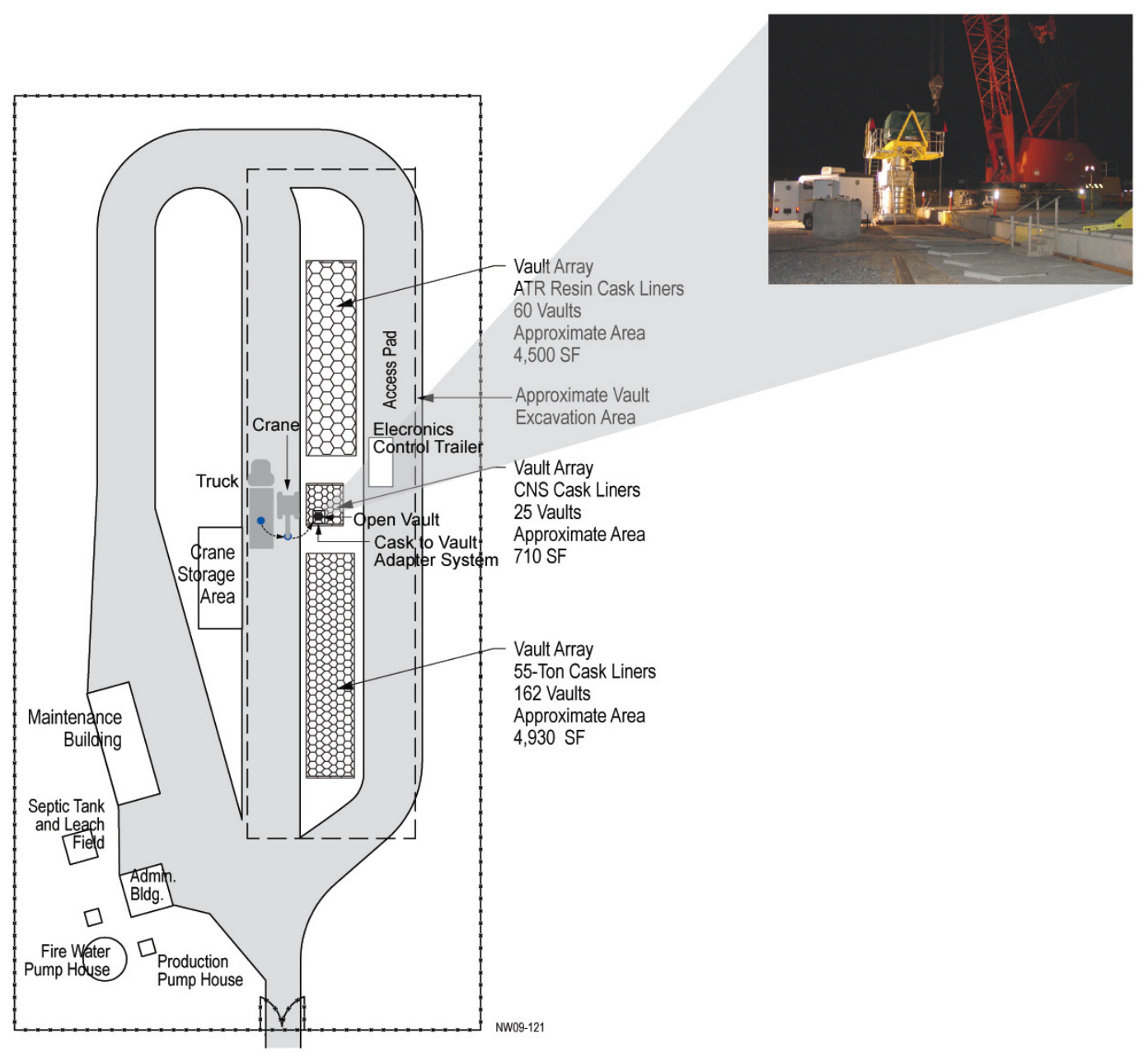

Figure 2. Remote-Handled Low-Level Waste Disposal Project operational configuration.

The following are major components of the proposed facility:

- Vaults - The vaults will be aligned vertically to allow multiple remote-handled LLW containers to be stacked on top of the previous one inserted in a vertical orientation. Vaults used to dispose of NRF waste will be designed to interface with the existing cask-to-vault adapting structure (CVAS) and the 55-ton scrap cask. Remaining vaults will be designed to interface with the appropriate transportation package and associated transfer system.

- Vault plugs - A removable concrete plug will be set in place on top of each of the stacked cylinder vaults. The plug will serve as a radiation shield for placed waste and will act as a water barrier to prevent surface water intrusion into the concrete vaults.

- Crane - The crane that is currently in use at RWMC will be disassembled, refurbished, and transported to the new disposal facility. This crane is a mobile two-track crane with a lifting capacity of approximately 140 tons $(127,000 \mathrm{~kg})$. If it is determined that the existing crane will not be available, a new crane with similar lifting capacity will need to be procured for the facility. 
- Waste container-Remote-handled LLW will be packaged into steel waste containers at the generating facilities. One waste container at a time is shipped within a shielded transportation package from the generating facility to the disposal facility. Upon arrival at the appropriate vault array location, the waste container will be transferred from the transportation package into the concrete vault. These waste containers perform an important safety function as a contamination barrier.

- CVAS - The CVAS currently located at RWMC will be transferred to the new disposal facility. All supporting equipment and components, such as the lifting rigging and control trailer, also will be made available for use.

- Staging and storage area-Staging and storage pads will be provided within the facility for operating equipment. These pads will be constructed using pit run gravel with a crushed gravel top surface. Areas will be provided for storage of the crane; the CVAS components, including the working platform; the bearing pad; the shield plug; and the electrical control trailer.

- Administrative and other supporting infrastructure - Additional support and administrative structures and services are included in the conceptual design, which include the following:

-Administration building

-Electrical distribution

-Maintenance enclosure

-Temporary transportation package holding area

-Equipment decontamination

-Access roads

-Video monitoring

-Firewater supply.

Additional details of these listed facility components may be found in the conceptual design report (INL 2010a).

\section{PROCESS OPERATION}

This section describes the overall process used for disposal of remote-handled LLW in concrete vaults at INL. Figure 3 shows the general process that currently is being used for NRF remote-handled LLW disposal in the vaults at RWMC. It is assumed that all future waste received from each of INL's generating facilities will be received and disposed of using this same, or similar, sequence of activities.

Remote-handled LLW destined for disposal will be packaged into shielded transportation packages with waste containers. The waste containers will normally consist of cylindrical containers designed specifically for the transportation package systems used. It is assumed that remote-handled LLW will be transported from NRF to the proposed disposal facility using the same 55-ton scrap cask that is used at RWMC (see Figure 4). Operations involving this cask will be substantially the same as those used at RWMC. The operational system associated with transportation packages and transfer systems used by other INL generators will be determined once specific waste container designs and transportation package systems are identified. 


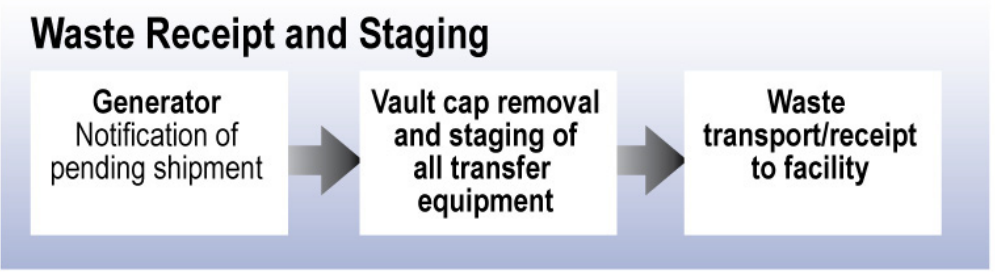

\section{Disposal}

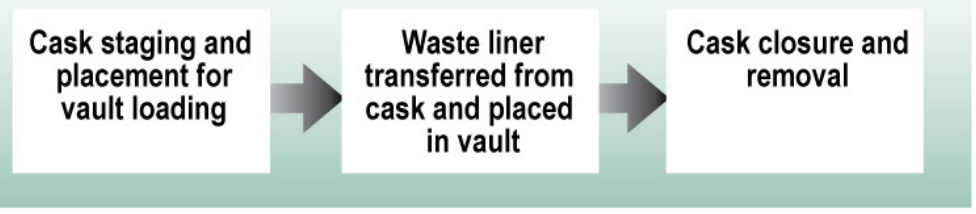

\section{Vault Closure and Demobilization}

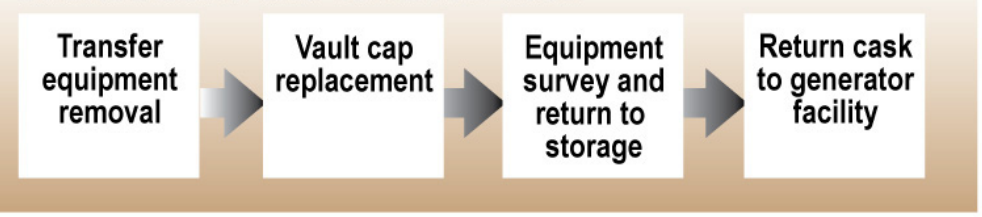

NW09-120

Figure 3. Facility process flow diagram.

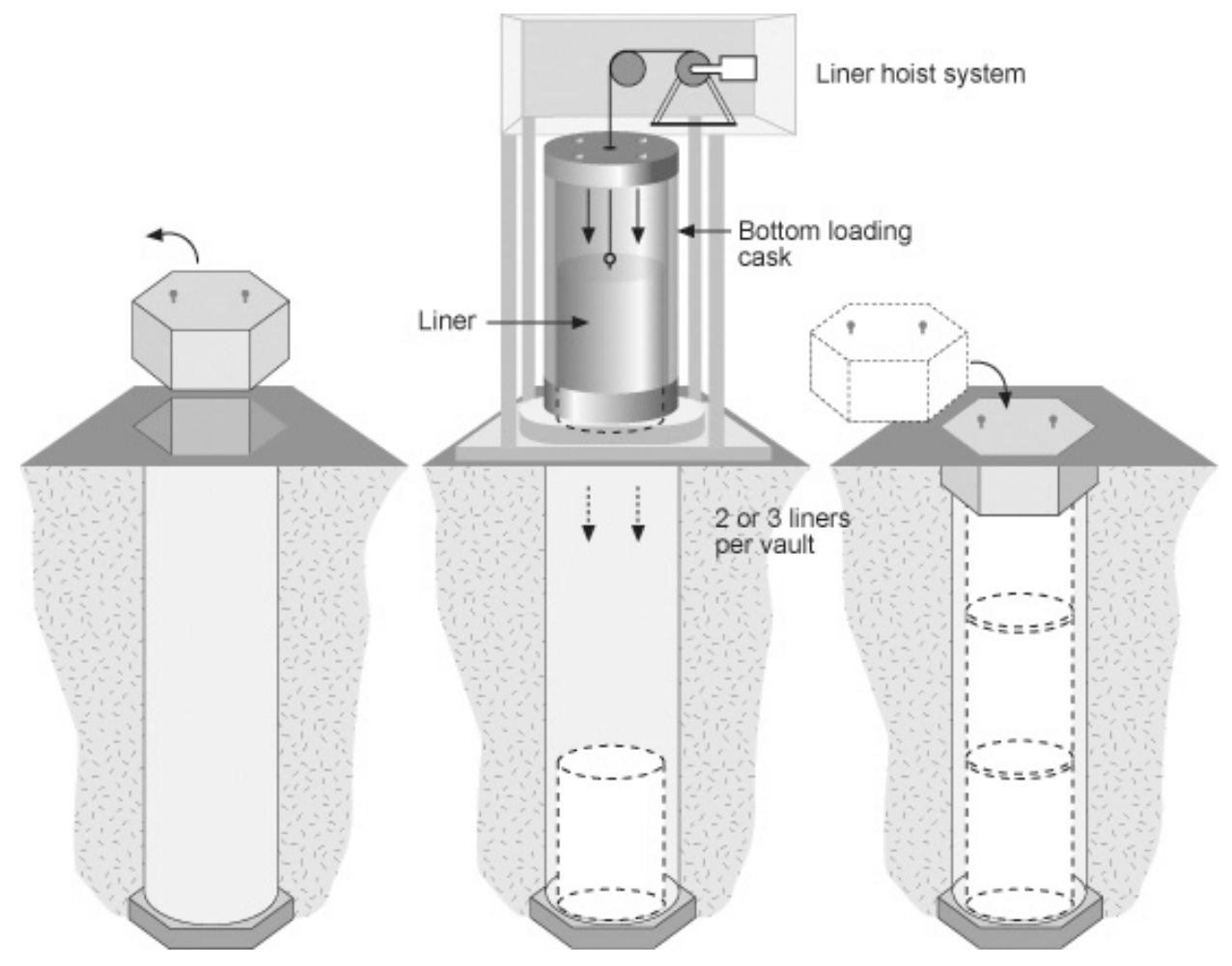

Figure 4. Cask liner placement method at the Radioactive Waste Management Complex. 
Only one waste container will be transported at any one time. No safety and health monitoring or surveillance, other than normal radiological surveys, is anticipated to be required as a part of normal operations. There may be additional surveillances required during transport and handling of specific waste containers with greater than 30,000-R/hour contact exposure rates. These requirements will be identified as part of the hazard and accident analysis process.

The current NRF waste container placement process consists of the following steps:

1. Once waste is transported to the site (using the NRF 55-ton scrap cask), a crane is used to remove the top plug on the vault and to position the CVAS on top of the open vault.

2. The 55-ton scrap cask is removed from the transporter and placed on the CVAS using the crane.

3. Using a remote-operated hoisting system, the cask liner is unloaded from the bottom of the cask and lowered into the disposal vault.

4. The cask is then closed and the hoisting system with the associated equipment is removed from the top of the vault.

5. The vault is then closed.

Specific operational systems and placement procedures that will be used in association with the other transportation package systems that will be used for disposal of the remote-handled LLW at the proposed facility will be determined once the generating facilities identify their specific waste container configurations. It is assumed that the following general operational sequence would be used for placement of the waste container into the associated disposal vaults:

1. Once waste is transported to the site, a crane will be used to remove the top plug on the vault and prepare the vault opening for waste container placement.

2. Using the crane, the waste container will be removed from the transportation package using the associated waste container handling equipment and appropriate shielding and will be positioned over the disposal vault.

3. The waste container will be lowered into the disposal vault.

4. The transfer equipment will be removed and the vault plug replaced.

\section{PRELIMINARY HAZARD CATEGORIZATION}

Based on the preliminary assessment of the anticipated remote-handled LLW streams and a comparison with DOE-STD-1027-92, "Hazard Categorization and Accident Analysis Techniques for Compliance with DOE Order 5480.23, Nuclear Safety Analysis Reports," the Remote-Handled LLW Disposal Project would have an initial hazard categorization of a Hazard Category (HC)-2 nuclear facility. This preliminary categorization is documented in the Safety Design Strategy for the

Remote-Handled Low-Level Waste Disposal Project (INL 2010c). The total Remote-Handled LLW Disposal Project radioactive material inventory anticipated to be present in the facility at a given time will exceed the HC-2 threshold quantity values for several radionuclides per DOE-STD-1027-92. However, DOE-STD-1027-92 supplemental guidance provides for facility categorization modification in the final hazard categorization process considering 1) alternative release fractions or 2) change in material subject 
to an accident due to facility features that preclude bringing material together or causing harmful interaction from a common severe phenomenon (facility segmentation).

The waste streams that will be accepted for storage at the Remote-Handled LLW Disposal Project must meet the requirements for LLW as specified in DOE Order 435.1, "Radioactive Waste Management." These requirements specify that the material must contain less than $100 \mathrm{nCi} / \mathrm{g}$ transuranic radionuclides. At this level, there would be less than $0.34 \mathrm{Ci}$ in the largest (i.e., $3,400 \mathrm{~kg}$ ) waste container. For a maximum of three waste containers per vault, this is equivalent to a maximum transuranic inventory of $1.02 \mathrm{Ci}$. The maximum vault inventory is compared to threshold quantities for HC-3 and HC-2 as discussed in DOE-STD-1027-92. Fractions of the respective threshold quantities for HC-3 and HC-2 for ${ }^{239} \mathrm{Pu}$ are 2.0 and 0.02 , respectively. Using ${ }^{239} \mathrm{Pu}$ as the representative transuranic radionuclide is considered conservative because the inhalation dose conversion factor for ${ }^{239} \mathrm{Pu}$ is the highest for all transuranic radionuclides that are likely to be present.

In terms of radionuclides that contribute to direct radiation exposure consequences, the maximum inventory is based on identifying radioactive material inventories that do not exceed the $30,000 \mathrm{R} / \mathrm{hr}$ contact exposure rate specified in the technical and functional requirements and the conceptual design report as the shielding design basis for transport and loading activities involving individual waste containers. In addition, the technical and functional requirements specify $2000 \mathrm{Ci}^{60} \mathrm{Co}$ as the design basis for the vault shield plugs. This value is considered bounding for non-transuranic radionuclides that are anticipated to be present in activated metal and resin waste streams because the HC-2 threshold quantity for ${ }^{60} \mathrm{Co}$ is significantly higher $(190,000 \mathrm{Ci})$.

Based on these waste stream inventories, individual vaults can be categorized as HC-3. Individual vaults can be considered separate facility segments per guidance in DOE-STD-1027-92, based on the following:

- $\quad$ Each vault will consist of three pre-cast concrete cylinders stacked on end and vertically aligned. Each vault will be buried in an array with a sand backfill that will completely separate the individual vaults.

- $\quad$ Each vault will be placed on a concrete vault foundation and will have a separate removable concrete plug placed on top of the cylinder to serve as a radiation shield and water barrier.

- $\quad$ Once these vaults are completely buried, there are no facility operations that can bring the contents of more than a single vault together. Once a vault is filled with up to three waste containers, the vault plug is put in place, thereby isolating the vault from the adjacent vaults comprising the array.

Because the individual vaults at the Remote-Handled LLW Disposal Project can be considered individual facility segments, and the maximum hazard categorization for a single vault is no greater than HC-3, the hazard category for the Remote-Handled LLW Disposal Project can be HC-3. This position will be further evaluated during development of the preliminary documented safety analysis and documented safety analysis per NS-18101, "INL Safety Analysis Process," to determine if modification to the initial facility hazard category is appropriate based on alternative release fractions or additional facility segmentation consideration. 


\section{IDENTIFICATION OF PRIMARY FACILITY HAZARDS}

This PHA was completed after a thorough review of the technical and functional requirements (TFR-83) and the conceptual design report (INL 2010a) for the proposed disposal facility and discussions with the project manager and other personnel associated with the project. From review of the facility technical and functional requirements, conceptual design report, and previous lessons learned, an analysis for potential hazards was performed. Results of this analysis are found in Table 2, which includes hazards and initiators that should be considered as the design progresses and the safety-basis documentation is being prepared. This table lists identified hazards and causes and possible preventative and mitigative responses. The table is not intended to be all-inclusive and may be updated, as required. In addition, some hazards in the table may extend beyond the scope outlined in the technical and functional requirements and conceptual design report. This presentation of potential hazards will be used in future analyses to determine whether further accident evaluation is warranted. At the time the safety-basis documentation is developed, some potential accidents may be eliminated from further consideration. They are included here because operational experience suggests that further consideration should be given. This list will be periodically reviewed and updated as additional hazards are identified in the facility design process.

Consequence evaluation of the postulated accident scenarios associated with the proposed facility requires a qualitative evaluation of those hazards. This evaluation encompasses internal events, man-made external events, accident initiators at nearby facilities, and natural phenomenon hazards. Sabotage and terrorism are not addressed in the analysis. Internal events occur as a result of facility operations and encompass all operational modes.

Hazard identification involves determining the following for the facility:

1. The material at risk (i.e., the type and amount of radioactive and hazardous material that is potentially releasable), including the form and location of the material

2. Potential energy sources and initiating events that could directly result in injury to workers or affect the inventory of radioactive and hazardous materials.

With respect to material at risk, the maximum radionuclide content of any waste container for the purposes of evaluating inhalation dose consequences is $0.34 \mathrm{Ci}$ transuranic (see Section 5). Although there may be specific waste streams with significantly higher Curie quantities of other radionuclides, this level of transuranic material results in the highest inhalation dose consequences from an airborne release due to the high dose conversion factors. Assuming that this material is released in powder form, the maximum inhalation dose consequences are less than $1 \mathrm{rem}$ to the facility worker and are negligible.

With respect to direct radiation exposure consequences, a 30,000 $\mathrm{R} / \mathrm{hr}$ contact exposure rate (see Section 5) results in consequences of $\sim 10$ rem to the facility worker for an exposure duration of two minutes in the absence of appropriate shielding and/or handling procedures during transfer operations and vault storage. For waste containers with contact exposure rates $>30,000 \mathrm{R} / \mathrm{hr}$, the consequences can be higher.

It should be noted that some of the waste streams may contain combustible materials such as plastics and other combustible radioactive waste. Waste containers with resins also may be subject to radiolytic water decomposition (i.e., hydrogen production) or corrosion-induced waste container failure during long-term storage. All of these specific materials were considered individually during development of the PHA, including likelihood and consequence evaluation. 
Hazardous chemical inventories for construction and operation of the remote-handled LLW disposal facility are very low in comparison to other INL operations and are commensurate with existing RWMC remote-handled LLW operations. No chemicals found in the Occupational Safety and Health Act substance-specific standards have been identified that would create a potential for exposure triggering medical surveillance during construction or operation. Additionally, no highly hazardous chemicals listed in 29 CFR 1910.119, "Process Safety Management of Highly Hazardous Chemicals," (Appendix A, List of Highly Hazardous Chemicals, or Toxics and Reactives) will be generated, used, or disposed of at this facility.

The likelihood category reflects a qualitative estimate of whether the hazardous event is anticipated, unlikely, extremely unlikely, or beyond extremely unlikely using the definitions in Table 2 . The likelihood of a hazardous event is generally the frequency of the initiating event or cause. No credit is taken for controls (i.e., design or administrative) that prevent the event. For an internal event (i.e., events initiated by equipment failure or human error), this generally results in a likelihood category of anticipated (i.e., $10^{-2}$ to $10^{-1}$ per year) because the frequency can depend on the facility design and operation. The likelihood category is based on available data, operating experience, and engineering judgment. If there is uncertainty in the likelihood category, the higher likelihood category is conservatively assumed.

The consequence category reflects a qualitative estimate of potential consequences to the offsite public, collocated workers, and facility workers from the hazardous event. A consequence category of high, moderate, low, or negligible is assigned for each receptor based on the unmitigated quantity of radioactive or hazardous material potentially released and the energy source for dispersion. Unmitigated means that a material's quantity, form, location, dispersibility, and interaction with available energy sources are considered, but no credit is taken for safety features (e.g., ventilation system or fire suppression) that could mitigate a hazard. If there is uncertainty in the consequence category, the more severe consequence category is conservatively assumed.

Safety-class SSCs are hazard controls for which credit is taken, either preventive or mitigative, to meet the evaluation guidelines for the offsite public. Based on the results in this PHA, evaluation guidelines for the public are not challenged for unmitigated releases. Therefore, no safety-class SSCs are identified for this facility.

Safety-significant SSCs are hazard controls for which credit is taken to prevent or mitigate postulated anticipated or unlikely accidents that could result in consequences to collocated or facility workers exceeding 5 rem (anticipated event) or 25 rem (unlikely event). Based on the results in this PHA, it is concluded that the potential exists for an accident that could result in direct radiation exposure exceeding these guidelines to the facility worker. The 5 -ft-thick concrete shield plugs are identified as a component that would protect the facility worker from these consequences after the waste containers are placed in the vaults. In addition, the CVAS and any shielding required for top-unloading transportation packages are identified as components that would protect the facility worker from these consequences during placement of the waste containers in the vaults. The shield plugs, CVAS, and shielding required for top-unloading transportation packages may be designated as safety-significant SSCs for design and facility planning purposes. As the facility design matures, further analyses will be performed, evaluating the direct radiation exposure to the facility worker from the specific material being transferred and stored. 


\section{CONCLUSIONS}

This PHA is a tool that will provide safety analysis and design teams a frame of reference as their activities commence. It identifies potential hazards and initiators that should be considered as the design process begins and that will continue to be considered through approval of the final documented safety analysis. Having a common frame of reference at the onset helps avoid potential late design modifications and will result in a safer facility. Based on the preliminary hazard categorization, the proposed RemoteHandled LLW Disposal Project total facility radionuclide inventory is sufficient to categorize the facility as $\mathrm{HC}-2$. A revised hazard categorization considers the possibility of reducing the categorization to HC-3 based on facility segmentation.

The list of potential hazards identified in this PHA is intended to be an outline for development of a detailed hazards analysis and facility safety-basis documents. It incorporates extensive experience and lessons learned from other facility nuclear safety designs and operations. The current stage of the design process does not require detailed analysis of accidents. The shield plugs, CVAS, and shielding required for top-unloading transportation packages may be designated as safety-significant SSCs for design and facility planning purposes. Detailed analyses will be completed in conjunction with development of the preliminary documented safety analysis and documented safety analysis. At this time, it is prudent to establish the thought processes necessary to develop accident scenarios for the preliminary documented safety analysis.

As the project design matures, generation of other safety documents and analyses will be required. These supporting documents, other than operational procedures, will include, as appropriate, a fire hazard analysis, conceptual safety design report, preliminary safety design report, preliminary documented safety analysis, documented safety analysis (DOE approval required) to supplement the INL's standardized documented safety analysis, hoisting and rigging plan, engineering design files, as-low-as-reasonably achievable reviews, radiation work permits, operational job safety analyses, construction project safety and health plan, and industrial hygiene exposure assessments prepared in accordance with associated INL procedures. 
Table 2. Preliminary hazards identified for the Remote-Handled Low-Level Waste Disposal Project.

\begin{tabular}{|c|c|c|c|c|c|c|}
\hline \multirow{2}{*}{ Scenario Description } & \multirow{2}{*}{$\begin{array}{l}\text { Likelihood } \\
\text { Category }^{\text {a }}\end{array}$} & \multirow{2}{*}{\multicolumn{2}{|c|}{$\begin{array}{c}\text { Unmitigated } \\
\text { Consequence Category }^{b} \\
\end{array}$}} & \multirow{2}{*}{ Safety Functions } & \multicolumn{2}{|c|}{ Potential Preventive and Mitigative Features } \\
\hline & & & & & Design $^{c}$ & Administrative $^{c}$ \\
\hline \multicolumn{7}{|l|}{ Fire and Explosion Hazards } \\
\hline $\begin{array}{l}\text { Large transport vehicle fire, } \\
\text { resulting in transportation } \\
\text { package/waste container failure, } \\
\text { ignition of combustible remote- } \\
\text { handled LLW, and release of } \\
\text { radioactive material }\end{array}$ & $\mathrm{U}$ & $\begin{array}{l}\text { Offsite public: } \\
\text { Collocated workers: } \\
\text { Facility workers: }\end{array}$ & $\begin{array}{l}\mathrm{N} \\
\mathrm{N} \\
\mathrm{N}\end{array}$ & $\begin{array}{l}\text { Prevent } / \text { mitigate } \\
\text { radioactive material } \\
\text { release due to fire }\end{array}$ & $\begin{array}{l}\text { Robust transportation } \\
\text { packages/waste containers } \\
\text { function as fire barrier }(\mathrm{P}) \\
\text { Facility fire suppression system } \\
\text { (M) }\end{array}$ & $\begin{array}{l}\text { Fire protection program }(\mathrm{P}) \\
\text { INL fire department response } \\
(\mathrm{M}) \\
\text { Equipment maintenance and } \\
\text { inspection }(\mathrm{P})\end{array}$ \\
\hline $\begin{array}{l}\text { Waste container drop during } \\
\text { placement into vault, resulting in } \\
\text { waste container failure, ignition of } \\
\text { combustible remote-handled LLW, } \\
\text { and release of radioactive material }\end{array}$ & $\mathrm{U}$ & $\begin{array}{l}\text { Offsite public: } \\
\text { Collocated workers: } \\
\text { Facility workers: }\end{array}$ & $\begin{array}{l}\mathrm{N} \\
\mathrm{N} \\
\mathrm{N}\end{array}$ & $\begin{array}{l}\text { Prevent } / \text { mitigate } \\
\text { radioactive material } \\
\text { release due to fire }\end{array}$ & $\begin{array}{l}\text { Robust waste containers } \\
\text { function as fire barrier }(\mathrm{P}) \\
\text { Facility fire suppression system } \\
\text { (M) }\end{array}$ & $\begin{array}{l}\text { Fire protection program }(\mathrm{P}) \\
\text { INL fire department response } \\
(\mathrm{M}) \\
\text { Equipment maintenance and } \\
\text { inspection }(\mathrm{P})\end{array}$ \\
\hline $\begin{array}{l}\text { Hydrogen buildup inside waste } \\
\text { container, resulting in waste } \\
\text { container breach and release of } \\
\text { radioactive material }\end{array}$ & $\mathrm{U}$ & $\begin{array}{l}\text { Offsite public: } \\
\text { Collocated workers: } \\
\text { Facility workers: }\end{array}$ & $\begin{array}{l}\mathrm{N} \\
\mathrm{N} \\
\mathrm{N}\end{array}$ & $\begin{array}{l}\text { Prevent } / \text { mitigate } \\
\text { radioactive material } \\
\text { release due to hydrogen } \\
\text { buildup in waste container }\end{array}$ & $\begin{array}{l}\text { Robust waste containers } \\
\text { function as fire barrier }(\mathrm{P}) \\
\text { Facility fire suppression system } \\
\text { (M) }\end{array}$ & $\begin{array}{l}\text { Fire protection program }(\mathrm{P}) \\
\text { INL fire department response } \\
(\mathrm{M}) \\
\text { Equipment maintenance and } \\
\text { inspection }(\mathrm{P})\end{array}$ \\
\hline \multicolumn{7}{|l|}{ Radioactive Material Release Hazards } \\
\hline $\begin{array}{l}\text { Loss of confinement due to } \\
\text { transportation package breach } \\
\text { caused by human error or } \\
\text { mechanical failure during unloading } \\
\text { of truck, resulting in release of } \\
\text { radioactive material and direct } \\
\text { radiation exposure }\end{array}$ & $\mathrm{A}$ & $\begin{array}{l}\text { Offsite public: } \\
\text { Collocated workers: } \\
\text { Facility workers: }\end{array}$ & $\begin{array}{l}\mathrm{N} \\
\mathrm{N} \\
\mathrm{L}\end{array}$ & $\begin{array}{l}\text { Prevent/mitigate } \\
\text { radioactive material } \\
\text { release and direct } \\
\text { radiation exposure during } \\
\text { transportation package } \\
\text { handling operations }\end{array}$ & $\begin{array}{l}\text { Solid waste form }(\mathrm{M}) \\
\text { Robust transportation package } \\
\text { (M) }\end{array}$ & $\begin{array}{l}\text { Employee training }(\mathrm{P}) \\
\text { Equipment maintenance and } \\
\text { inspection }(\mathrm{P}) \\
\text { Hoisting and rigging program } \\
(\mathrm{P}) \\
\text { Immediate worker evacuation } \\
(\mathrm{M}) \\
\text { Vehicle speed limits }(\mathrm{P})\end{array}$ \\
\hline
\end{tabular}


Table 2. Preliminary hazards identified for the Remote-Handled Low-Level Waste Disposal Project.

\begin{tabular}{|c|c|c|c|c|c|c|}
\hline \multirow{2}{*}{ Scenario Description } & \multirow{2}{*}{$\begin{array}{l}\text { Likelihood } \\
\text { Category }^{\text {a }}\end{array}$} & \multirow{2}{*}{\multicolumn{2}{|c|}{$\begin{array}{c}\text { Unmitigated } \\
\text { Consequence Category }^{\mathrm{b}}\end{array}$}} & \multirow{2}{*}{ Safety Functions } & \multicolumn{2}{|c|}{ Potential Preventive and Mitigative Features } \\
\hline & & & & & Design $^{c}$ & Administrative $^{c}$ \\
\hline $\begin{array}{l}\text { Loss of confinement due to waste } \\
\text { container breach caused by human } \\
\text { error or mechanical failure during } \\
\text { placement of container into vault, } \\
\text { resulting in release of radioactive } \\
\text { material and direct radiation } \\
\text { exposure }\end{array}$ & A & $\begin{array}{l}\text { Offsite public: } \\
\text { Collocated workers: } \\
\text { Facility workers: }\end{array}$ & $\begin{array}{l}\mathrm{N} \\
\mathrm{N} \\
\mathrm{L}\end{array}$ & $\begin{array}{l}\text { Prevent/mitigate } \\
\text { radioactive material } \\
\text { release and direct } \\
\text { radiation exposure during } \\
\text { waste container handling } \\
\text { operations }\end{array}$ & $\begin{array}{l}\text { Solid waste form }(\mathrm{M}) \\
\text { Waste container integrity }(\mathrm{M}) \\
\text { Waste container transfer } \\
\text { system shielding }(P)\end{array}$ & $\begin{array}{l}\text { Employee training }(\mathrm{P}) \\
\text { Equipment maintenance and } \\
\text { inspection }(\mathrm{P}) \\
\text { Hoisting and rigging program } \\
(\mathrm{P}) \\
\text { Immediate worker evacuation } \\
(\mathrm{M})\end{array}$ \\
\hline $\begin{array}{l}\text { Loss of confinement due to } \\
\text { corrosion-induced waste container } \\
\text { failure during storage caused by } \\
\text { corrosive agents contained in resins, } \\
\text { resulting in release of radioactive } \\
\text { material }\end{array}$ & $\mathrm{U}$ & $\begin{array}{l}\text { Offsite public: } \\
\text { Collocated workers: } \\
\text { Facility workers: }\end{array}$ & $\begin{array}{l}\mathrm{N} \\
\mathrm{N} \\
\mathrm{N}\end{array}$ & $\begin{array}{l}\text { Prevent } / \text { mitigate } \\
\text { radioactive material } \\
\text { release during storage }\end{array}$ & $\begin{array}{l}\text { Vault storage design }(\mathrm{P}) \\
\text { Vault storage completely } \\
\text { enclosed underground }(\mathrm{M})\end{array}$ & $\begin{array}{l}\text { Radiation protection program } \\
(\mathrm{P})\end{array}$ \\
\hline $\begin{array}{l}\text { Loss of confinement due to } \\
\text { corrosion-induced waste container } \\
\text { failure during storage caused by } \\
\text { water intrusion into vault, resulting } \\
\text { in release of radioactive material }\end{array}$ & $\mathrm{U}$ & $\begin{array}{l}\text { Offsite public: } \\
\text { Collocated workers: } \\
\text { Facility workers: }\end{array}$ & $\begin{array}{l}\mathrm{N} \\
\mathrm{N} \\
\mathrm{N}\end{array}$ & $\begin{array}{l}\text { Prevent } / \text { mitigate } \\
\text { radioactive material } \\
\text { release during storage }\end{array}$ & $\begin{array}{l}\text { Vault storage design (P) } \\
\text { Vault storage completely } \\
\text { enclosed underground (M) } \\
\text { Vault storage designed to } \\
\text { minimize potential water } \\
\text { infiltration (M) }\end{array}$ & $\begin{array}{l}\text { Radiation protection program } \\
\text { (P) }\end{array}$ \\
\hline \multicolumn{7}{|l|}{ Direct Radiation Exposure Hazards } \\
\hline $\begin{array}{l}\text { Direct radiation exposure due to loss } \\
\text { of transportation package shielding } \\
\text { caused by human error or } \\
\text { mechanical failure during unloading } \\
\text { of transport vehicle }\end{array}$ & A & $\begin{array}{l}\text { Offsite public: } \\
\text { Collocated workers: } \\
\text { Facility workers: }\end{array}$ & $\begin{array}{l}\mathrm{N} \\
\mathrm{N} \\
\mathrm{H}\end{array}$ & $\begin{array}{l}\text { Prevent/mitigate direct } \\
\text { radiation exposure during } \\
\text { transportation package } \\
\text { handling operations }\end{array}$ & $\begin{array}{l}\text { Robust transportation package } \\
\text { (M) }\end{array}$ & $\begin{array}{l}\text { Employee training }(\mathrm{P}) \\
\text { Equipment maintenance and } \\
\text { inspection }(\mathrm{P}) \\
\text { Hoisting and rigging program } \\
(\mathrm{P}) \\
\text { Immediate worker evacuation } \\
(\mathrm{M}) \\
\text { Vehicle speed limits }(\mathrm{P})\end{array}$ \\
\hline
\end{tabular}


Table 2. Preliminary hazards identified for the Remote-Handled Low-Level Waste Disposal Project.

\begin{tabular}{|c|c|c|c|c|c|c|}
\hline \multirow{2}{*}{ Scenario Description } & \multirow{2}{*}{$\begin{array}{l}\text { Likelihood } \\
\text { Category }^{a}\end{array}$} & \multirow{2}{*}{\multicolumn{2}{|c|}{$\begin{array}{c}\text { Unmitigated } \\
\text { Consequence Category }^{\mathrm{b}}\end{array}$}} & \multirow{2}{*}{ Safety Functions } & \multicolumn{2}{|c|}{ Potential Preventive and Mitigative Features } \\
\hline & & & & & Design $^{c}$ & Administrative $^{c}$ \\
\hline $\begin{array}{l}\text { Direct radiation exposure during } \\
\text { waste container (less than } \\
30,000 \mathrm{R} / \text { hour) transfer to vault }\end{array}$ & A & $\begin{array}{l}\text { Offsite public: } \\
\text { Collocated workers: } \\
\text { Facility workers: }\end{array}$ & $\begin{array}{l}\mathrm{N} \\
\mathrm{N} \\
\mathrm{L}\end{array}$ & $\begin{array}{l}\text { Prevent/mitigate direct } \\
\text { radiation exposure during } \\
\text { waste container handling } \\
\text { operations }\end{array}$ & $\begin{array}{l}\text { Waste container transfer } \\
\text { system shielding }(P)\end{array}$ & $\begin{array}{l}\text { Radiation protection program } \\
(\mathrm{D}, \mathrm{M}) \\
\text { Employee training }(\mathrm{P})\end{array}$ \\
\hline $\begin{array}{l}\text { Direct radiation exposure during } \\
\text { waste container (greater than } \\
30,000 \mathrm{R} / \text { hour) transfer to vault }\end{array}$ & $\mathrm{U}$ & $\begin{array}{l}\text { Offsite public: } \\
\text { Collocated workers: } \\
\text { Facility workers: }\end{array}$ & $\begin{array}{l}\mathrm{N} \\
\mathrm{N} \\
\mathrm{H}\end{array}$ & $\begin{array}{l}\text { Prevent/mitigate direct } \\
\text { radiation exposure during } \\
\text { waste container handling } \\
\text { operations }\end{array}$ & $\begin{array}{l}\text { Waste container transfer } \\
\text { system shielding }(\boldsymbol{P}) \\
\text { Temporary shielding }(\mathrm{M})\end{array}$ & $\begin{array}{l}\text { Radiation protection program } \\
(\mathrm{D}, \mathrm{M}) \\
\text { Employee training }(\mathrm{P}) \\
\text { Specific procedures for } \\
\text { transferring waste containers } \\
\text { with high contact exposure } \\
\text { rates }(\mathrm{P})\end{array}$ \\
\hline \multicolumn{7}{|l|}{ External Events } \\
\hline $\begin{array}{l}\text { Radioactive or hazardous materials } \\
\text { released during vault storage due to } \\
\text { external events (e.g., plane crash, } \\
\text { vehicle crash, or adjacent building } \\
\text { fire/explosion) }\end{array}$ & EU & $\begin{array}{l}\text { Offsite public: } \\
\text { Collocated workers: } \\
\text { Facility workers: }\end{array}$ & $\begin{array}{l}\mathrm{N} \\
\mathrm{N} \\
\mathrm{N}\end{array}$ & $\begin{array}{l}\text { Prevent } / \text { mitigate } \\
\text { radioactive material } \\
\text { release during vault } \\
\text { storage }\end{array}$ & $\begin{array}{l}\text { Facility design }(\mathrm{P}) \\
\text { Vault storage completely } \\
\text { enclosed underground }(\mathrm{M})\end{array}$ & Appropriate facility siting (M) \\
\hline \multicolumn{7}{|l|}{ Natural Phenomena Hazard Events } \\
\hline $\begin{array}{l}\text { Radioactive material released due to } \\
\text { Natural Phenomena Hazard (e.g., } \\
\text { tornado, flood, range fire, lightning, } \\
\text { or volcanoes) }\end{array}$ & $\mathrm{U}$ & $\begin{array}{l}\text { Offsite public: } \\
\text { Collocated workers: } \\
\text { Facility workers: }\end{array}$ & $\begin{array}{l}\mathrm{N} \\
\mathrm{N} \\
\mathrm{N}\end{array}$ & $\begin{array}{l}\text { Prevent } / \text { mitigate } \\
\text { radioactive material } \\
\text { release during vault } \\
\text { storage }\end{array}$ & $\begin{array}{l}\text { Facility design }(\mathrm{P}) \\
\text { Vault storage completely } \\
\text { enclosed underground }(\mathrm{M})\end{array}$ & Appropriate facility siting (M) \\
\hline $\begin{array}{l}\text { Direct radiation exposure due to loss } \\
\text { of vault shield plug integrity caused } \\
\text { by severe seismic event }\end{array}$ & EU & $\begin{array}{l}\text { Offsite public: } \\
\text { Collocated workers: } \\
\text { Facility workers: }\end{array}$ & $\begin{array}{l}\mathrm{N} \\
\mathrm{N} \\
\mathrm{H}\end{array}$ & $\begin{array}{l}\text { Prevent/mitigate direct } \\
\text { radiation exposure during } \\
\text { vault storage }\end{array}$ & Vault shield plug $(P)$ & $\begin{array}{l}\text { Surveillance program }(\mathrm{P}) \\
\text { Immediate worker evacuation } \\
(\mathrm{M}) \\
\text { Emergency response } \\
\text { procedures }(\mathrm{M})\end{array}$ \\
\hline \multicolumn{7}{|c|}{$\mathrm{A}=$ anticipated $\left(10^{-2}\right.$ to $10^{-1} /$ year $) ; \mathrm{U}=$ unlikely $\left(10^{-4}\right.$ to $10^{-2} /$ year $) ; \mathrm{EU}=$ extremely unlikely $\left(10^{-6}\right.$ to $10^{-4} /$ year $) ; \mathrm{BEU}=$ beyond extremely unlikely $\left(\right.$ less than $\left.10^{-6} / \mathrm{year}\right)$} \\
\hline
\end{tabular}

